Available online at GSC Online Press Directory

GSC Biological and Pharmaceutical Sciences

e-ISSN: 2581-3250, CODEN (USA): GBPSC2

Journal homepage: https://www.gsconlinepress.com/journals/gscbps

(RESEARCH ARTICLE)

\title{
Description of soil impurity for Elbasan city - Albania
}

\author{
Anila Jançe ${ }^{1, *}$, Valentin Bogoev ${ }^{1}$ and Admir Jançe ${ }^{2,3}$ \\ ${ }^{1}$ Sofia University "St. Kliment Ohridski", Sofia, Bulgaria. \\ 2 "European University of Tirana", Tirana, Albania. \\ 3"AleksanderXhuvani" University, Elbasan, Albania.
}

Publication history: Received on 15 November 2020; revised on 23 November 2020; accepted on 26 November 2020

Article DOI: https://doi.org/10.30574/gscbps.2020.13.2.0378

\begin{abstract}
This scientific paper enables us to present the bacteriological, physico-chemical parameters and heavy metals present in the soil of Elbasan city. Through this study we have obtained significant data that give us the opportunity to judge about soil impurity of Elbasan city, allowing us to present a current assessment of soil pollution.

The pollution of the land of a historical-cultural city like Elbasan takes on a considerable importance in terms of the impact on the health of citizens, based mainly on the cultivation of agricultural crops in the study area.

In view of this goal, during the September-October 2020 period, some soil samples were taken and analyzed in the laboratory, where the area predetermined by us for samples taking consists of the geographical space where the heavy industries of Elbasan city operate. All bacteriological, physico-chemical parameters and heavy metals part of the soil of Elbasan are presented for the first time in this paper.

As a result of the results obtained where we encounter a significant soil pollution of Elbasani town we think that is attributed to the fact that Elbasan has always been considered as one of the most polluted cities in Albania in recent years.

Finally, we can say that land pollution comes as a result of productive activities of light and heavy industries, which operate without implementing the rules of environmental protection in Albania but also from human activity mainly in agriculture, where we mention the use without criteria of pesticides and chemical fertilizers.
\end{abstract}

Keywords: Bacteriological; Physico-chemical; Heavy metals; Soil impurity; Agricultural crops; Elbasan city

\section{Introduction}

In this scientific paper are given bacteriological, physico-chemical and heavy metals data, present in the soil of Elbasan city. Microorganisms are present everywhere in air, water and soil, being primarily responsible for the transmission of various diseases and food pollution [1,2]. As for the pollution of the earth by heavy metals, this is dedicated to the activity of heavy industries and mining, always being the object of scientific research by academic institutions. The presence of heavy metals above the permitted norms is a permanent risk to human health as a result of water pollution and vegetation. Misuse and indiscriminate use of land, its erosion and the productive activity of heavy industries, constantly damage natural resources $[2,3,4]$.

*Corresponding author: PhD. Anila Jançe

Sofia University "St. Kliment Ohridski", Sofia, Bulgaria.

Copyright (C) 2020 Author(s) retain the copyright of this article. This article is published under the terms of the Creative Commons Attribution Liscense 4.0. 
Heavy metals always remain essential for vegetation as long as they are within the allowed norms, otherwise disorders in metabolism and inhibition of normal growth for them, mainly affecting the catalytic functions of enzymes, abnormal development of roots and shoots, reduce the process of absorption of carbon dioxide, etc. [5].

Heavy metals present in the soil have a definite $\mathrm{pH}$ value, below which their solubility undergoes a significant increase. We find them underground in the form of ionic, colloidal, dissolved phase forms. Heavy metals present a good affinity for acids, clays and oxides [6].

There is a phenomenon that with decreasing $\mathrm{pH}$, solubility and mobility of heavy metals increases, this is also the reason that the $\mathrm{pH}$ of the soil is a key factor that controls the solubility, mobility and absorption of nickel mainly, and why they play a secondary role in such as: iron-manganese minerals, soil clay content and organic matter [7, 8]. Judging by the results obtained for heavy metals, it is concluded that all are below the critical values recommended by the Albanian state and the EU, with the exception of only nickel present at levels significantly higher than the set criteria.

Other international research papers $[5,9,10]$ have concluded that the highest existence of Ni in the unlamented soils was present in residual pool. This is thought to be due to Nickel's ability to the highest crystal field stabilization energy among the common divalent metals and thus, has a high potential to be enriched in clay minerals [11]. The reactivity of $\mathrm{Ni}$ appears higher in alkaline and neutral soils in comparison with acidic soil [9]. The main purpose of this scientific paper was to provide sufficient data on soil pollution in Elbasan area during the September-October 2020 period, as well as to give the impact that this pollution has on human life. In order to perform the highest quality analyzes on soil pollution for Elbasan city, we have conducted three types of analyzes: microbiological, physico-chemical and heavy metals. Through the samples provided and then analyzed, we tried to shed light on the factors that affect the pollution of Elbasani town soil.

\section{Material and methods}

Twenty eight soil samples were obtained for analysis at a deepness of 15 to $50 \mathrm{~cm}$ a two-month period, concretely in September-October 2020 in Elbasan area. For the speciation analysis, a determination in water soil extracts was performed by applying the colorimetric method diphenylcarbazide [12].

So $2.5 \mathrm{~g}$ soil samples were shaken with $25 \mathrm{ml}$ of demineralized water for 2.5 hours. After centrifugation for $10 \mathrm{~min}$ at $3500 \mathrm{rpm}$, the water was filtered through a $0.45 \mu \mathrm{m}$ Millipore filters [13]. Instantly after extraction, the sample was acidified with a drop of concentrated ultrapure $\mathrm{HNO}_{3}$ to bring the $\mathrm{pH}<2$. To minimize valence changes, analysis were carried out within less than $24 \mathrm{~h}$ after extraction.

Sober soil pH (after standard calibration at pH 4-7) in a suspension of $10 \mathrm{~g}$ of soil in $25 \mathrm{ml}$ demineralized water, after magnetic stirring for $30 \mathrm{~min}$, succeeding by 5 min sediment precipitation. The analysis of the grain size performed on $10 \mathrm{~g}$ of sample was treated initially with $1 \mathrm{M} \mathrm{HCl}$ to remove the calcareous material, then oxalic acid for Fe release and $\mathrm{H} 2 \mathrm{O} 2$ for organic release.

\section{Results and discussion}

Based on the observation of the obtained results we come to the judgment that all soil samples analyzed for Elbasan city, confirm the fact that this city has significant soil pollution, as many of the analyzed elements are above the recommended norms.

Table 1 Microbiological analysis of soil samples

\begin{tabular}{|l|l|l|l|}
\hline No. & Microbiological index & Recommended content CFU/100ml & Content found CFU/100ml \\
\hline 1 & Escherichia coli (E. Coli) & $0-100$ & 0 \\
\hline 2 & Enterococci & $0-100$ & 310 \\
\hline 3 & Coliform bacteria & $0-100$ & 540 \\
\hline
\end{tabular}


All the results obtained for the two-month period analyzed are presented together in order to perceive soil pollution as realistically as possible, also this grouping enables us to compare the results obtained with the defined normative values.

Table 1 shows the microbiological pollution of the soil. We single out Escherichia coli only, as the other two species of pathogenic bacteria, Enterococci and Coliforms are present in soil samples analyzed above the recommended norms. Traditionally, the analysis of soil microorganisms in relatively polluted areas has always found a significant presence of aerobic bacteria, nitrogen-fixing microorganisms and fungi $[1,4]$.

Table 2 is constructed to present the physico-chemical parameters of the analyzed soil. Examining this table it is concluded that, we find that Ammonium (NH4 +) and Potassium (K) are the only substances that have values significantly higher than the recommended norms, while all other physico-chemical parameters are presented at the appropriate levels.

Table 2 Physico-chemical analysis of soil samples

\begin{tabular}{|l|l|l|l|}
\hline No. & Parameter & Recommended content $(\mathbf{m g} / \mathbf{l})$ & Content found $(\mathbf{m g} / \mathbf{l})$ \\
\hline 1 & $p H$ & $6.5-8.35$ & 8.1 \\
\hline 2 & Sulphates $\left(\mathrm{SO}_{4}{ }^{--}\right)$ & 40 & 23.2 \\
\hline 3 & Nitrites $\left(\mathrm{NO}_{2}-\right)$ & 0.5 & 0.28 \\
\hline 4 & Ammonium $\left(\mathrm{NH}_{4}^{+}\right)$ & 0.1 & 0.58 \\
\hline 5 & Phosphates $\left(\mathrm{P}_{2} \mathrm{O}_{5}\right)$ & 1 & 0.69 \\
\hline 6 & Magnesium $(\mathrm{Mg})$ & 10 & 2.1 \\
\hline 7 & Nitrates $\left(\mathrm{NO}_{3}^{-}\right)$ & 3 & 2.75 \\
\hline 8 & Chlorides $\left(\mathrm{Cl}^{-}\right)$ & 25 & 8.7 \\
\hline 9 & Aluminum & 40 & 9.8 \\
\hline 10 & Calcium $(\mathrm{Ca})$ & 20 & 13 \\
\hline 11 & Potassium $\left(\mathrm{K}^{-}\right)$ & 10 & 18.5 \\
\hline 12 & Carbonates $\left(\mathrm{CO}_{3}{ }^{-2}\right)$ & 30 & 25.5 \\
\hline
\end{tabular}

Table 3 Heavy metals of soil samples

\begin{tabular}{|l|l|l|l|}
\hline No. & Chemical elements & Recommended content $(\boldsymbol{\mu g} / \mathbf{l})$ & Content found $(\boldsymbol{\mu g} / \mathbf{l})$ \\
\hline 1 & Cadmium $(\mathrm{Cd})$ & 40 & 0.11 \\
\hline 2 & Arsenic $(\mathrm{As})$ & 350 & 15 \\
\hline 3 & Copper $(\mathrm{Cu})$ & 1500 & 247.5 \\
\hline 4 & Cobalt $(\mathrm{Co})$ & 820 & 269.6 \\
\hline 5 & Lead $(\mathrm{Pb})$ & 3200 & 274.5 \\
\hline 6 & Manganese $(\mathrm{Mn})$ & 3500 & 352.4 \\
\hline 7 & Zinc $(\mathrm{Zn})$ & 3200 & 432.4 \\
\hline 8 & Chromium $(\mathrm{Cr})$ & 2100 & 988.2 \\
\hline 9 & Nickel $(\mathrm{Ni})$ & 800 & $\mathbf{1 2 5 1}$ \\
\hline 10 & Iron $(\mathrm{Fe})$ & 62000 & 14380 \\
\hline
\end{tabular}


Table 3 shows the presence of heavy metals in the soil. From its observation it is concluded that only the chemical element of Nickel (Ni) is significantly higher in values than those recommended, thus becoming the key factor of soil pollution, while all the rest of the heavy metals analyzed appear within the allowed parameters.

Welch and Lund [14] reviewed the impact of soil moisture order on metal mobility after sewage sludge addition and discover that less leaching of Ni occurred under saturated conditions (3.3\% of applied $\mathrm{Ni}$ ) than under unsaturated conditions (10.7\%). Nickel is mainly a metal with a significant presence and sufficiently distributed in the earth's crust. Its presence in the soil is conditioned or favored by the concentration of nickel in the parent rocks, while for surface soils; its quantitative presence is a reflection of soil formation processes and pollution that the soil may have undergone [15].

For years now, Elbasan city has been labeled as one of the most polluted cities in Albania. This considerable and prolonged pollution (mainly caused by heavy metals) is dedicated in our opinion to the release into the atmosphere of various gases from the technological industries mainly smelting and refining that operate in Elbasan area. When these elements are present in the atmosphere, easily between air, water and soil, they can pass into the human food chain, through daily processes such as: air absorption, drinking water and food consuming [16]. Nickel is classified as a heavy metal with a significant weight in the environmental pollution of urban cities where as its source serve technological activities, but as a source that leads to its excess in the soil can be the lowering of the soil $\mathrm{pH}$, which is why due to reduced use of soil lime on agricultural lands and water discharges resulting from acid rain in industrialized areas [17, 18].

Based on the obtained results we can say that the factors that affect soil pollution are

- Bacteriological - Discharge of wastewater

- $\quad$ Physico-chemical - pollution of agricultural land mainly from disheveled use of pesticides

- Heavy metals - deposited on the ground by industrial activity in Elbasan

\section{Conclusion}

- Elbasan city soil is regarded contaminated starting from the following tests:

- Microbiological: Coliform bacteria and Enterococci appear above the allowed norms.

- Physico-chemical: Ammonium and Potassium are evidently up the approved values.

- Heavy metal: Nickel results far above the recommended criteria.

- Soil impurity that occurs for Elbasani town, we are mainly of the thought that more than human activity in agriculture and improper wastewater treatment, it is more dedicated to the productive activity performed by heavy industries in Elbasan city.

\section{Compliance with ethical standards}

\section{Acknowledgments}

I would like to express my sincere gratitude to the supervisor Prof. Valentin Bogoev for the support and proper scientific guidance in the realization of this scientific work, as well as the staff of Natural Sciences Faculty, "Aleksander Xhuvani" University, Elbasan, to provide the necessary conditions for conducting laboratory analysis.

\section{Disclosure of conflict of interest}

The authors declare that there is no conflict of interest for the presented study.

\section{References}

[1] Madigan M, Martinko J, Stahl D, Clark D. Brock Biology of Microorganisms. 13th ed. Upper Saddle River, New Jersey: Pearson Prentice Hall Education. 2006; 1096.

[2] Bogoev V, Kenarova A, Traykov I, Tzonev R, Tzekova R, Stoyanova T, Boteva S, Parleva N. Biotechnology. 2010; 24: $240-246$. 
[3] Mantovi P, Bonazzi G, Maestri E, Marmiroli N. Accumulation of copper and zinc from liquid manure in agricultural soils and crop plants. Perugia: Journal of Plant and Soil. 2003; 249-257.

[4] Jançe A. Palynological study of Quaternary deposits in the Elbasan city. Monografi, Tirana: "Julvin 2"; $2015 ; 140$.

[5] Sims JT, Kline JJ. Chemical fractionation of plant uptake of heavy metals in soils amended with co-composted sewage sludge. J. Environ. Qual. 1991; 20: 387-395.

[6] Elliot HA, Liberali MR, Huang CP. Competitive adsorption of heavy metals by soils. Journal of Environ. Qual. 1986; 15: 214-219.

[7] Ge Y, Murray P, Hendershot WH. Trace metal speciation and bioavailability in urban soils. Environ. Poll. 2000; 107: 137-144.

[8] Suavé S, Hendershot W, Allen E. Solid - solution partitioning of metals in contaminated soils: Dependence on pH, total metal burden, and organic matter. Environ. Sci. Technol. 2000; 34(7): 1125-31.

[9] Han FX, Banin A, Triplett GB. Redistribution of heavy metals in arid-zone soils under a witting-drying cycle soil moisture regime. Soil Sci. 2001; 166(1): 18-28.

[10] Rajaie M, Karimian N, Yasrebi J. Nickel transformation in two calcareous soil textural classes as affected by applied nickel sulfate. Geoderma. 2008; 144(1-2): 344-351.

[11] Bruemmer GW, Gerth J, Tiller KG. Reaction kinetics of the adsorption and desorption of nickel, zinc and cadmium by goethite. I. Adsorption and diffusion of metals. J. Soil Sci. 1988; 39: 37-51.

[12] Darrie G. Commercial extraction technology and process waste disposal in the manufacture of chromium chemicals from ore. Environmental Geochemistry and Health. 2001; 23: 187-193.

[13] Armienta MA, Rodrigues R, Ceniceros N, Juares F, Cruz O. Distribution, origin and fate of chromium in soils in Guanajuato, Mexico. Environmental Pollution. 1996; 91(3): 391-397.

[14] Welch JE, Lund LJ. Soil properties, irrigation water quality and soil moisture level influences on the movement of nickel in sewage sludge treated soils. J. Environ. Qual. 1987; 16: 403-410.

[15] Mcllveen WD, Negusanti JJ. Nickel in terrestrial environment. Sci. Total Environ. 1994; 148: 109-138.

[16] Gazso LG. The Key Microbial Processes in the Removal of Toxic Metals and Radionuclides from the Environment. A review. Hungary: Central European Journal of Occupational and Environmental Medicine. 2001; 7(3): 178-185.

[17] Bencko V. Nickel: A review of its occupational and environmental toxicology. J. Hyg. Epidem. Micro. Immun. 1983; 27: 237-247.

[18] Cempel M, Nikel G. Nickel: A review of its sources and Environmental Toxicology. Polish J. of Environ. Stud. 2006; 15(3): 375-382. 